\title{
Nomadology, the Nomad, the Concept
}

\section{Jon Roffe}

There is, in my view, a list of five or six very unfortunate things written or spoken by Gilles Deleuze. Here is one of the most egregious:

Yes, that's what a theory is, exactly like a tool box ... A theory has to be used, it has to work. And not just for itself. If there is no one to use it, starting with the theorist himself who, as soon as he uses it ceases to be a theorist, then a theory is worthless, or its time has not yet arrived. You don't go back to a theory, you make new ones, you have others to make. It is strange that Proust, who passes for a pure intellectual, should articulate it so clearly: use my book, he says, like a pair of glasses to view the outside, and if it isn't to your liking, find another pair, or invent your own, and your device will necessarily be a device you can fight with. ${ }^{1}$

This seemingly innocuous, somewhat interesting, passagefrom a discussion with Foucault called 'Intellectuals and Power' - has given rise to, or at least underpinned, some of the most depressing, underwhelming and pointless works of 'critical theory' produced in the last thirty years. It has been taken as a licence to engage in a kind of free-form conceptual snatch and grab, where one's favourite object of contemplation can be given rigour through the magical words 'Using the concept of the nomad in Deleuze, I will argue that ...'

More specifically, the problem is that-in the lion's share of cases - the concept is conceived as the manifestation of a particular talismanic power rather than the bearer of specific 
intellectual content and theoretical construction. Indeed, for all the talk of challenging the hegemonic status quo, what is kept intact is precisely the form of hierarchical authority. This is all made so much worse by the fact that the content, the concept itself, tends towards the absolutely arbitrary. Emboldened by this tool-box talk, we use the concepts however we like, ignoring what they were in the first place. In fact, this whole tragicomedy is a game of proper names: the proper names of our (mostly French) masters, the proper names of concepts, and our proper names. The apparent free-form activity of the radical intellectual is nothing other than the marriage of an extreme subservience to institutionalised authority and an extreme self-indulgence close to malignant narcissism. For, at the very least, if we take concepts to be tools without understanding what they are in their singularity, they become, one and all, clubs.

The worst examples of this kind of situation are found in the 'uses' to which the proper names Gilles Deleuze and Félix Guattari, and the names of their concepts - for example, the rhizome, or the nomad-are put. While thinkers smoke the rhizome pipe and rhapsodise about imagined nomadic lines of flight, the university grows more rigid, harder, colder; if possible, even crueller.

I could go on. Now, imagine my surprise when I first read Reading the Country, which makes heavy use of French theory, and whose single most prominent concept is that of the nomad and its cognates. For in fact what we find here is the toolbox approach succeeding. I don't want to give the impression that I think Reading the Country is the perfect 'application' of Deleuze and Guattari's concept. I do have reservations on a number of points, to say nothing of the fact that the very notion of 'application' is part of the problem that Muecke's approach entirely avoids. However, what we do find here, I think, is a genuine example of what Deleuze and Guattari think theory - really, thinking as such - can and should be like. And it does so with one of the most interesting, complicated, maligned and misused of the many concepts found in the infamous A Thousand Plateaus: nomadology.

It does this in three important ways. First of all, the political system of proper names is not given any more 
significance than it deserves, which is none. If Deleuze and Guattari's concepts are used, and this is the second point, they are not treated as essential framework into which the particular case of the country and the situation of Australia is slotted. The concepts - entirely in keeping with Deleuze and Guattari's own edicts on this situation - are deployed as equal parts of the work (along with paintings, photographs, discussions, and so on), one case of the material composition of the work, rather than as master tropes. Finally, Reading the Country succeeds in showing how the concept gains its critical force by simply treating it as what it is: a concept. Here concept is opposed to something like precept or maxim, something I'll come back to at the end of this piece.

In this pause in the flow of invective, I would like to quite briefly reflect on the account of nomadology that is presented in Reading the Country (particularly in the final chapter), in light of its success at the level of its deployment.

\section{The nomad in Deleuze}

The social category of the nomad and the nomadic, and its concomitant conception of thought that they call nomadology, is a particular focus of two late chapters in Gilles Deleuze and Félix Guattari's A Thousand Plateaus. However, the opposition there between nomadic and sedentary is already at issue in Deleuze's earlier work Difference and Repetition. He introduces it as one half of a pair of concepts, nomos and logos, which he contends are concepts pertaining to 'hierarchy and distribution', which is to say, hierarchy and ordering. ${ }^{2}$

The word nomos itself, normally translated as 'law', has its roots in the more ancient root nem, which describes the pasturing of animals - hence the word nemo: 'To take to pasture.'3 Instead of the land being parcelled up in advance, the sheep were free to wander, giving rise to the organisation of space as a secondary effect rather than presupposing it, as in the modern cattle industries. This is already illuminating, but let me briefly add to it by noting two interrelated characteristics belonging to logos and nomos respectively.

The first point is specifically organisational. The form of distribution that is governed by logos is one that assumes a fixed order of reality to which things can conform or diverge 
from. The problem of good organisation - of a life, a city, a community, and so on - is thus one of imposing a rule in a transcendent fashion, without attention to the specificities of what will be brought under the rule. There is a converse form of distribution or organisation proper to nomos.

It is not the case, contrary to Badiou's infamous and pseudonymous critique, that the nomadic designates a lack of organisation. ${ }^{4}$ Deleuze is very clear on this point: 'The question has always been organizational.'5 In turn, nomadic organisation is not anarchic, but rather eschews the transcendence of a structure or a rule in favour of the dynamic practice of organising.

Let me note in passing the great irony of the common use of the concept of the nomad in the humanities: to the degree that it is deployed as a locus of intellectual authority, transcendent in relation to the material it is 'applied' to, this common use is essentially aligned with logos rather than nomos. This is ironic, but not in a funny way.

The second point concerns spatiality. Deleuze will align the distribution of logos with what he calls 'sedentary space'. 6 Sedentary space is that which is broken up in accordance with the logos and its modes of distribution. This is the space of a city map, of an office, but also the stratification of organisational roles, rules governing correct or appropriate discourse and the uses of bodies, and so on. In contrast, nomadic space is smooth - which is to say it has no a priori structure before it is occupied. 'Here,' Deleuze writes, 'there is no longer a division of that which is distributed but rather a division among those who distribute themselves in an open space.'7

When we turn to A Thousand Plateaus, we see the analysis extended more explicitly in the direction of a social analysis. There, they argue that the nomadic is a form of social organisation, one that has no place for fixed social structure. In fact, the point is a stronger one: nomadic societies are actively hostile to the kind of structure deployed by the state. The category of the war machine, which is central to their analysis, expresses in the first instance this hostility, the war machine being nothing but the corrosive capacity of nomadic societies to undo fixed social formations, the state formation in particular. This generalised hostility is true not just in terms 
of things like lines of filiation and descent, but is also registered, Deleuze and Guattari argue in divergent conceptions and deployments of science, thinking, weaponry, writing and warfare. Together these features fall under the title of 'nomadology', and we find an excellent gloss of this long discussion in 'Strategic Nomadology: An Introduction', the penultimate section of Reading the Country.

As in Difference and Repetition, though, the analysis has a distinctive, even primary, spatial register. In a certain sense, nomadic societies can be characterised as at once evading the state striation of space and constructing a smooth space. This is why Deleuze and Guattari will say: 'Nomadism is precisely this combination of war-machine and smooth space.'8 The hostility towards state organisation has as its obverse the practical constitution of a smooth space, in which movement is not to and from fixed places, but instead a generalised condition, a state against the State.

Before continuing, it is important to note that all of these oppositions (smooth/striated, nomadic/sedentary, nomos/ logos) are distinctions in principle. This is to say that in fact we never find a social organisation that is strictly nomadic, just as even the most rigid state organisation nonetheless gives rise to its own ambulatory, peripatetic elements, and its own smooth spaces. There is no place, therefore, to speak of a pure exteriority. As Muecke argues in the excellent 'Bricolage' chapter, any assertion that de facto absolute oppositions hold is, in reality, a fantasy: 'Discarding Western clothing does not reduce one to a state of nature.'

\section{Nomadology in Reading the Country}

All this brings us to Reading the Country proper. I have talked about how the concept of the nomad is used, but now a few words about what it is used to do. There are quite a lot of things to be said here, but I'll restrict myself to two.

1. The first important move that Muecke makes (I have hinted at this already) is to realise that nomad and nomadology designate concepts to be treated on their own terms, rather than descriptive categories to be judged in terms of their adequation to reality. In the words of Ron Bogue: 'Deleuze and Guattari's object is not to systematise received anthropological 
taxonomies; rather, it is to articulate two tendencies - the nomadic and the sedentary - that have each a certain inner coherence and that manifest themselves in various mixed forms.' ${ }^{10}$ Muecke was perhaps the first to recognise this, and to anticipate already both the entire debate that would take place about the 'accuracy' of Deleuze and Guattari's analysis and its resolution at the level of the concept.

Ultimately, concepts are, for Deleuze and Guattari, to be used. It is hard to disagree, therefore, with Muecke's assessment: " "nomadology' is ... an exotic import, from the writings of Deleuze and Guattari. How did they see this "empty spindle" being used? No doubt they would welcome its aberrant usage in the Kimberleys.'11

For this reason, though, I think we must disagree with another of Reading the Country's assertions, the claim that the book 'has appropriated nomadology as a metaphor'.12 The metaphor, as both a rhetorical figure and a mechanism in the circulation of sense, presupposes the state organisation of language, with its hold on the category of the literal, and its regulation of value. Concepts, on the other hand, and with Deleuze and Guattari, are never metaphors, since they function directly at the same level as everything else.

2. I said earlier that there cannot be, in Deleuze and Guattari's view, a nomadic society in fact and as such, since all such social groups include in them other divergent tendencies too. Paddy Roe recognises this in his discussion of the term 'nomad', and it is marked at a number of other points in Reading the Country, for example:

while the marauding armies of nomads like Genghis Khan have disappeared, and the conditions for their existence no longer pertain, nomadism as a set of practices still survives in all sorts of ways. Traditional ways of living have a habit of not dying off completely, even when modern society seems to have quite decisively closed the book on the past. They persist as ideas or as practices and even now the 'progress' we have made can be measured afresh in their light. ${ }^{13}$

Muecke here marks the fact that this co-implication of nomad and state goes both ways, for processual elements 
of nomadism continue to exist in the Australian capitalist state, alongside the other vectors of organisation the terms 'state' and 'capitalism' imply. What is decisive, therefore, is not exactly the postulation of a nomadic social formation, even in principle, but the location of a series of processes and practices that cut against state organisation and give rise to a smooth space: this is precisely what we can understand by the phrase 'Strategic Nomadology'. Muecke presents on this front the excellent example of the lobby:

Nomadism has always infiltrated even the heart of government. There is, for instance, the swarming and ambiguous group of the lobby - sometimes comprised of members holding state positions, sometimes not, trading in favours and secrets, always mobilised towards specific tasks. The two groups, government and lobby, are dependent on each other for their mutual functioning, yet they are animated by different sorts of esprit de corps, they have many characteristics which are opposite. The lobby has 'secret' workings, while government presents public positions. ${ }^{14}$

\section{The concept as nomad}

I would like to conclude by returning to my own proper territory, philosophy. A realisation has slowly dawned on me this week as I reread Reading the Country - and, of course, there is no such thing as reading the country, all reading being a rereading, every discovery a rediscovery, every reading always already writing. The realisation is this: that the concept is also a nomad. This is true even though its particular form of state formation and its smooth space are noetic, noological, belonging to thought rather than to the country. The smooth space of thought spreads out now as an heterogenous patchwork of topoi, places, rather than an interior closed volume proper to an individual, not 'in the head'.

The use of a concept can be measured then by the two criterion that belong to the nomadic: its capacity to break with the state of its situation, in the most general sense; and its capacity to engender a smooth space in thought. 
What is the state with which Reading the Country broke and continues to break? Certainly, the sociopolitical representation of Australia. But also and still a certain academic approach, one that neatly separates out life and reflection, practice and journal articles, since what it makes clear is that to speak, to write and to think happen among and at the same level as reality as such. This in turn is the smooth space that Reading the Country constructs.

\section{'No, l've never talked about the nomad'}

Since I've done nothing much here other than briefly dwell on this surprising conceptual success in Reading the Country, and its proximity to Deleuze and Guattari, I might finish by invoking one more thing that elicited not only a shock of recognition but also a loud guffaw. The book includes, of course, a chapter devoted to a kind of retrospective interview, where Muecke and Paddy Roe discuss the term 'nomad' itself, one that Paddy Roe tells us he hasn't heard before.

It reminded me of a line in Deleuze and Guattari's Anti-Oedipus, which is devoted in part, as I'm sure you know, to the concept of schizophrenia. In an interview after the book's published, they say that their favourite sentence is this: 'Someone asked us if we had ever seen a schizophrenicno, no, we have never seen one.' ${ }^{15}$ In books, as in social life and every other ensemble of creative practices, ${ }^{16}$ including philosophy, 'One does not represent, one engenders and traverses'. ${ }^{17}$ I imagined how good it would be to be able to sayno, I have never talked about the nomad-certainly never used in philosophical works - while nonetheless being engaged in that lyrical, principled passage of a thinking that never ceases.

\section{Notes}

1 Gilles Deleuze, Desert Islands and Other Texts, ed. David Lapoujade, trans. Michael Taormina, semiotext(e), New York, 2004, p. 208.

2 Gilles Deleuze, Difference and Repetition, trans. Paul Patton, Columbia University Press, New York, 1994, p. 36.

3 Gilles Deleuze and Félix Guattari, A Thousand Plateaus, trans. Brian Massumi, University of Minnesota Press, Minneapolis, 1987, p. 557, n. 51.

4 Georges Peyrol [Alain Badiou], 'Le Flux et le parti: dans les marges de L'AntiOedipe', Cahiers Yenan, no. 4, 1977, pp. 24-31. 
Gilles Deleuze and Claire Parnet, Dialogues, trans. Hugh Tomlinson and Barbara Habberjam, Athlone Press, London, 1987, p. 145.

6 Deleuze, Difference and Repetition, p. 36.

7 Ibid.

8 Gilles Deleuze, Negotiations, trans. Martin Joughin, Columbia University Press, New York, 1995, p. 33.

9 Krim Benterrak, Stephen Muecke and Paddy Roe, Reading the Country:

Introduction to Nomadology, Fremantle Arts Centre Press, Fremantle, 1984, p. 171.

10 Ronald Bogue, 'Apology for Nomadology', interventions, vol. 6, no. 2, 2004, p. 172.

11 Benterrak, Muecke and Roe, p. 241.

12 Ibid., p. 253.

13 Ibid., p. 243.

14 Ibid., p. 245.

15 Gilles Deleuze and Félix Guattari, Anti-Oedipus, trans. Robert Hurley, Mark Seem and Helen R. Lane, University of Minnesota Press, Minneapolis 1983, p. 380 .

16 Here I'm paraphrasing Reading the Country:

How does one find out about nomadism, or understand nomadology?

Firstly, there are texts, written or unwritten, from other cultures which pre-date the philosophical texts of Western capitalism. In this sense the ways in which many Australian Aboriginal people speak are free of the categories which articulate Western philosophies. Secondly, there are ways of living which are organised around movement, change and local politics. Then there is the imagination of the writer whose art eschews authority. All of these contribute to the study of nomadism.

Benterrak, Muecke and Roe, p. 241.

17 Deleuze and Guattari, A Thousand Plateaus, p. 364. 